\title{
Analisis Postur Kerja Posisi Memanjat pada Petani Gula Kelapa Kabupaten Banyumas
}

\author{
Rani Aulia Imran ${ }^{1 *}$, Ajeng Dian Purnamasari ${ }^{2}$, Ayu Anggraeni Sibarani ${ }^{3}$ \\ 1,3 Jurusan Teknik Industri, Fakultas Teknik, Universitas Jenderal Soedirman \\ Jln. Mayjen Sungkono Km. 5, Blater, Kalimanah, Purbalingga \\ 1*rani.aulia.imran@unsoed.ac.id, ${ }^{3}$ ayu.anggraeni.sibarani@unsoed.ac.id \\ ${ }^{2}$ Program Studi Pendidikan Jasmani, Kesehatan dan Rekreasi, Fakultas Ilmu-ilmu Kesehatan, Universitas \\ Jenderal Soedirman, Jln. Dr. Soeparno Karangwangkal Purwokerto. \\ 2ajeng.dian.purnamasari@unsoed.ac.id
}

Dikirimkan: 10, 2019. Diterima: 10, 2019. Dipublikasikan: 12. 2019

\begin{abstract}
Banyumas is one of the districts in Central Java that produces more than 20,000 tons of palm sugar production per year and occupies the first position of processing type agro-industry in Banyumas. The number of palm sugar farmers (penderes) in 2017 was 20,293 farmers. However, the number of farmers continues to decrease because the occupation has working risks and the safety of farmers is not guaranteed. The purpose of this study was to analyse the working posture of palm sugar farmers when climbing coconut trees. Video record of the process of taking nira (raw palm sugar) from 48 secondary data were collected. Each representative frame, with a complete gait cycles, were analysed to identify climbing postures and a literature review for reference. Posture evaluation uses REBA and calculated the risk score. The results showed six tree climbing positions have a very high risk of work posture with a score of 8 to 11, and the needs to contribute to change. Further research is needed to evaluate the musculoskeletal system that contributes to tree climbing activities and recommendations to reduce workplace risks, improve the health and welfare of palm sugar farmers.
\end{abstract}

Keywords - posture; climb up; farmers; coconut sugar; reba

\begin{abstract}
Abstrak- Banyumas adalah salah satu kabupaten di Jawa Tengah yang memproduksi lebih dari 20.000 ton produksi gula aren per tahun dan menempati posisi pertama agroindustri jenis pengolahan di Banyumas. Jumlah petani gula aren (penderes) pada tahun 2017 adalah 20.293 petani. Namun, jumlah petani ini terus berkurang karena pekerjaan sebagai penderes memiliki resiko kerja dan keselamatan dari petani belum terjamin. Tujuan dari penelitian ini adalah untuk menganalisis postur kerja petani gula aren saat memanjat pohon kelapa. Rekaman video proses pengambilan nira dari 48 data sekunder dikumpulkan. Setiap posisi representatif berdasarkan gait sequence memanjat dianalisis untuk mengidentifikasi postur memanjat dan tinjauan literatur untuk referensi. Evaluasi postur menggunakan REBA dan dihitung skor resikonya. Hasil penelitian menunjukkan bahwa enam posisi memanjat pohon memiliki risiko sangat tinggi dari pendekatan postur kerja dengan nilai skor 8 sampai 11, dan perlu adanya implementasi perubahan. Nilai skor REBA terbesar yakni 11 terjadi pada postur foot flat (10\%) dan midswing (80\%). Penelitian selanjutnya diperlukan untuk mengevaluasi sistem muskuloskeletal yang berkontribusi dalam kegiatan memanjat pohon dan rekomendasi untuk mengurangi risiko kerja, meningkatkan kesehatan dan kesejahteraan petani gula aren.
\end{abstract}

Kata kunci- postur; memanjat; petani; gula kelapa; reba.

\section{PENDAHULUAN}

Mayoritas tenaga kerja Indonesia bekerja di sektor informal berlokasi di daerah pedesaan, terutama sektor pertanian. Berdasarkan [1], petani di Indonesia rentan dan berisiko terhadap berbagai masalah kesehatan yang mempengaruhi produktivitas dan status kesehatan jangka panjang. Keselamatan dan kesehatan kerja merupakan aspek penting dalam menciptakan suasana kerja yang aman dan nyaman dengan tujuan mencapai produktifitas yang lebih baik [1] [2][3] serta dapat mengurangi resiko kecelakaan kerja dan munculnya penyakit akibat kerja. Resiko ini dapat disebabkan oleh berbagai jenis bahaya yakni bahaya mekanik, fisik, kimia, biologi, psikososial, dan ergonomi. Penyakit akibat kerja yang paling sering terjadi terkait dengan bahaya ergonomi adalah keluhan 
gangguan otot rangka akibat kerja (musculoskeletal disorder)[4], ini juga terjadi pada petani yang memanjat pohon kelapa [5].

Ergonomi merupakan suatu bidang ilmu yang mempelajari interaksi manusia pada suatu sistem dalam kaitannya dengan pekerjaan mereka. Faktor pekerjaan yang berhubungan dengan resiko gangguan muskuloskeletal dapat berasal dari paparan bahaya ergonomi salah satunya biomekanik berupa postur janggal. Postur netral adalah posisi anggota tubuh berada pada posisi yang sesuai dengan anatomi tubuh tanpa kontraksi otot berlebihan, sedangkan postur janggal adalah saat posisi anggota tubuh menyimpang dari posisi netral saat beraktivitas yang disebabkan oleh keterbatasan tubuh [6]. Walaupun manusia dapat memanjat pohon sejak lama, hal dipengaruhi oleh kekuaatan otot (lengan, bahu, dan kaki), persen lemak tubuh, body mass index, volume memanjat, dan pengalaman [7][8][9].

Banyumas merupakan salah satu kabupaten di Propinsi Jawa Tengah yang memproduksi lebih dari 20.000 ton gula aren per tahun [10]. Total 23 dari 27 kecamatan diantaranya adalah penghasil gula kelapa yang sebagian besar dipasarkan pada pasar lokal dan pasar ekspor sesuai dengan kualitas gula yang dihasilkan [11]. Pohon kelapa yang berumur 4-8 tahun sejak awal penanaman akan siap untuk dipanen, tetapi kualitas terbaik adalah pohon berusia 15-30 tahun [12]. Produksi kelapa dalam perkebunan rakyat Kabupaten Banyumas tahun 2015 memiliki luas areal 65.310 ha [13]. Oleh karena itu produk gula kelapa menempati posisi pertama agroindustri jenis pengolahan di Banyumas. Sebagai salah satu produk unggulan daerah, pemerintah menargetkan ekspor gula kelapa 30.000 ton/tahun [14]. Namun demikian, perlunya perhatian lebih terkait angka kecelakaan tinggi dan pemberian santunan kecelakaan yang belum merata, serta penerapan teknologi keselamatan masih dalam uji coba.

Petani gula aren pada tahun 2017 berjumlah 20.293 petani, tetapi jumlah ini terus berkurang karena kasus kecelakaan kerja yang masih tinggi sebagai salah satu pemicu sehingga pekerjaan ini tidak diminati kaum muda [15][16][17]. Stigma masyarakat bahwa menjadi petani gula aren bukanlah suatu pilihan, sehingga motivasi rendah bagi petani untuk mengarahkan anaknya ke profesi yang sama. Bagi petani yang berusia muda, memanjat puluhan pohon kelapa tidak menjadi masalah karena mereka mampu secara fisik. Tidak mudah setiap pagi dan sore petani harus memanjat 20-30 pohon kelapa sehari, masing-masing pohon memiliki diemeter berbeda dan tingginya mencapai lebih dari 10 meter.
Petani yang berusia 35 tahun ke atas lebih beresiko karena kecemasan jatuh dari pohon meningkat, dan rasa takut akan ketinggian yang dimanifestasikan dalam ketegangan otot [18][19].

Tercatat bahwa sejak awal tahun hingga bulan Oktober 2017 laporan ke Pemerintah Kabupaten Banyumas, menunjukkan $28 \%$ orang meninggal dunia dari 135 kasus korban terjatuh saat mengumpulkan nira kelapa. Kecelakaan kerja sering terjadi pada orang yang berusia lebih dari 45 tahun, di mana mayoritas pekerja berusia 3555 tahun [16]. Pada tahun 2016 ada 126 petani jatuh dari pohon kelapa, dengan kasus 52 tewas dan 74 mengalami cacat fisik. Hasil serupa disimpulkan oleh George dkk. [20] bahwa total $35,5 \%$ (78 kasus dari 220 pemanjat) jatuh dari pohon kelapa saat melakukan pekerjaan mereka. Total $7,9 \%$ dari pemanjat pohon menarik diri dari profesi tradisional mereka dan tetap menganggur, $5,3 \%$ berhenti memanjat pohon karena masalah kesehatan, dan 94,7\% mengundurkan diri karena cidera [5]. Penelitian oleh Edacheri dkk [21] juga melaporkan semakin sedikit petani gula aren yang mau untuk memanjat pohon kelapa.

Bappeda Litbang Kabupaten Banyumas melaksanakan focus group discussion bersama dengan berbagai stakeholder dalam rangka peningkatan kualitas dan kuantitas gula kelapa untuk mencapai target RPJMD 2018-2023. Keselamatan petani penderes, kompetensi penderes, pemberian santunan kecelakaan, usia penderes yang sudah tua, dan penerapan teknologi alat keselamatan adalah hal-hal yang menjadi bahan diskusi [22]. Pengembangan alat bantu dan alat keselamatan untuk memanjat pohon kelapa sudah ada baik berupa tangga, sabuk [22], kursi panjat [5][21], dan robot pengambil nira [23]. Agustus 2019 lalu dilakukan sosialisasi alat pengaman penderes dengan menggunakan sabuk yang merupakan modifikasi dari peralatan panjat tebing [22]. Berkat dukungan pemerintah dan pendanaan bank, alat BOCX3 diberikan kepada 50 penderes di Desa Pageraji untuk digunakan dan akan dievaluasi. Namun pada diskusi tersebut, belum ada evaluasi postur dari aktivitas kerja memanjat pohon kelapa untuk mengidentifikasi postur yang memiliki nilai resiko keselamatan kerja, dari sisi biomekanika.

\section{Metodologi Penelitian}

Tujuan dari penelitian ini adalah untuk menganalisis postur kerja petani gula aren saat memanjat. Tuntutan pekerjaan seperti memanjat pohon dapat dilakukan dengan mempelajari kaitannya dengan dinamika kaki dalam siklus berjalan (gait cycle), walapun dengan perubahan 
fungsi-fungsi ini dalam berjalan vertikal [20]. Kirtley [24] menggambarkan bahwa gaya berjalan didefinisikan sebagai metode gerak yang ditandai dengan periode bongkar muat (loadingunloading) anggota badan. Siklus yang biasa dimulai dengan kontak satu kaki dan diakhiri dengan kontak berikutnya dari kaki yang sama seperti Gambar 1 di bawah ini. Gait cycle terdiri dari dua fase yakni fase tumpuan (stance) dan mengayun (swing).

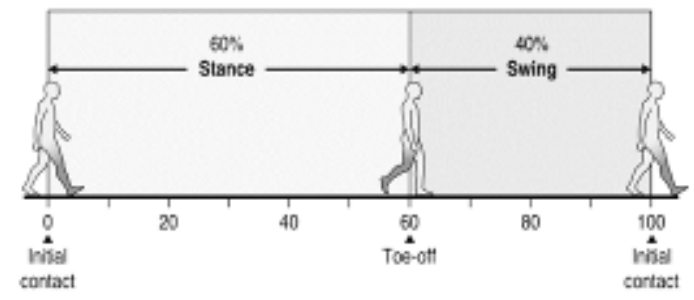

Gambar 1. Rangkaian gait (gait sequences) dari siklus gait berjalan [24]

Rekaman video dari 48 data sekunder dikumpulkan mengenai aktivitas kerja petani gula kelapa Banyumas saat memanjat untuk mengambil nira kelapa. Tidak semua video dapat menggambarkan siklus penuh petani kelapa saat memanjat pohon kelapa, sehingga total video yang memperlihatkan satu siklus gait lengkap berjumlah 34 video. Setiap frame representatif dianalisis untuk mengidentifikasi postur memanjat dan dikaitkan dengan tinjauan literatur terkait gait cycle dan analisis postur kerja. Setiap frame video pada 6 postur posisi siklus gait dilakukan evaluasi menggunakan Rapid Entire Body Assessment (REBA) dan menghitung besar resikonya [25].

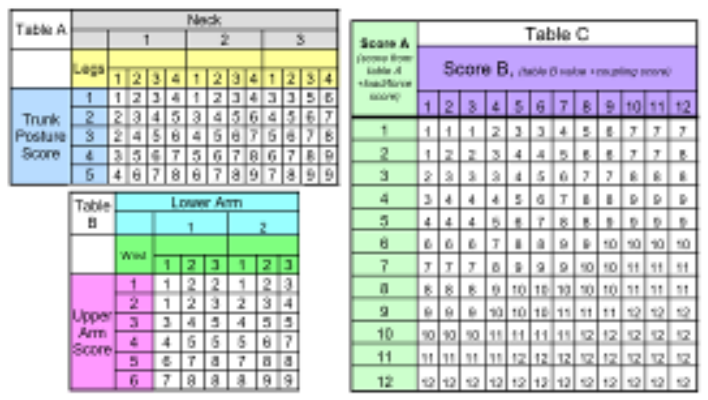

Gambar 2. Skor Rapid Entire Body Assessment (REBA) [25].

REBA seperti pada Gambar 2 terbagi menjadi dua area yakni bagian leher, badan, dan kaki sebagai masukan tabel $\mathrm{A}$, kemudian area lengan dan pergelangan tangan untuk masukan tabel B. Tabel $\mathrm{C}$ digunakan untuk menentukan skor berdasarkan skor dari skor A dan B untuk mendapatkan skor akhir. Skor akhir inilah yang akan diambil kesimpulan berapa besar resikonya.

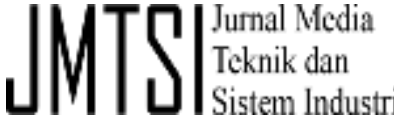

\section{HASIL PENELITIAN}

Data aktivitas memanjat dari penderes berjumlah total 33 orang petani laki-laki dan satu orang perempuan. Tidak seluruh video mencantumkan data identitas responden, namun dari keterangan hasil wawancara terdapat responden berusia 17 tahun dan ada pula yang berusia 62 tahun. Kecelakaan kerja terjadi sering pada penderes berusia lebih dari 45 tahun, dimana mayoritas penderes berusia 35-55 tahun [16] dan didominasi oleh petani usia tua. Penderes secara umum kurang gizi karena tingginya jam kerja dan tidak diimbangi asupan nutrisi yang cukup [26]. Hal ini juga ditunjukkan pada [1] bahwa petani Indonesia memiliki asosiasi dengan masalah gizi dan anemia.

\section{A. Gaya Memanjat}

Menurut penelitian oleh Kraft dkk [27], terdapat beberapa macam gaya memanjat pohon secara tradisional (tanpa alat bantu) yang teridentifikasi. Ada gaya memanjat menggunakan bantuan kain atau tali, gaya yang menyerupai olah raga panjat tebing [21], dan ada pula yang menggunakan tangan dan kaki memeluk pohon. Gaya memanjat para petani Kabupaten Banyumas memanjat pohon kelapa menggunakan gaya Chinbodn yang diilustrasikan pada Gambar 3.

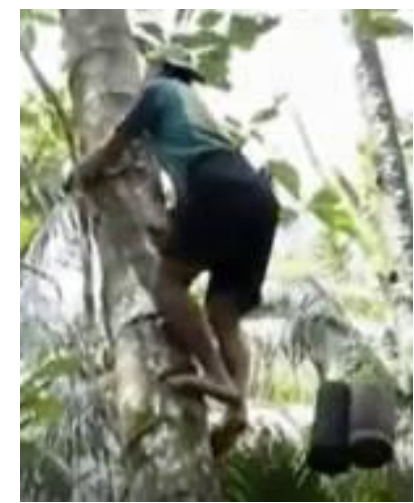

Gambar 3. Gaya Memanjat Petani Gula Aren Banyumas [28]

Gaya memanjat ini mengharuskan pemanjat memeluk pohon dengan kedua tangan, dengan lutut terentang, pandangan mengarah ke atas dan anggota gerak atas serta anggota gerak bawah menghasilkan kekuatan secara bergantian. Hal ini dilakukan dengan menggunakan gerakan inversi pergelangan kaki, abduksi pinggul, fleksi lutut, dan fleksi bahu [27]. Petani gula kelapa pada video $100 \%$ memanjat menggunakan pijakan yang telah dibuat sebelumnya dalam bentuk cekungan pada permukaan pohon kelapa. 


\section{B. Range Waktu Gait Sequence Saat Memanjat}

Gambar 3 menunjukkan kebutuhan waktu pada rangkaian gait saat memanjat. Variasi waktu yang paling banyak terjadi pada posisi $80 \%$ (midswing) dan 25\% (midstance). Memanjat secara teknik merupakan aktivitas yang sangat menuntut dan cukup kompleks dengan adanya perpindahan secara vertikal dan lateral, sehingga hampir semua otot tubuh berpartisipasi. Bila memiliki level kebugaran dan kekuatan maka dapat dengan mudah menyelesaikan pekerjaan memanjat pohon kelapa [29]. Variasi waktu pada Gambar 4 menunjukkan kebutuhan tenaga dalam melakukan setiap rangkaian gait. Kedua posisi dengan variasi terbanyak, midswing dan midstance, menunjukkan posisi menahan salah satu kaki dan mengayunkan kaki lainnya saat memanjat. Sejalan dengan Kirtley dkk [24] mengungkapkan ground reaction force dengan satuan newton $(\mathrm{N})$ pada normal gait saat kedua posisi ini (pada kaki yang tertumpu) adalah yang terbesar.

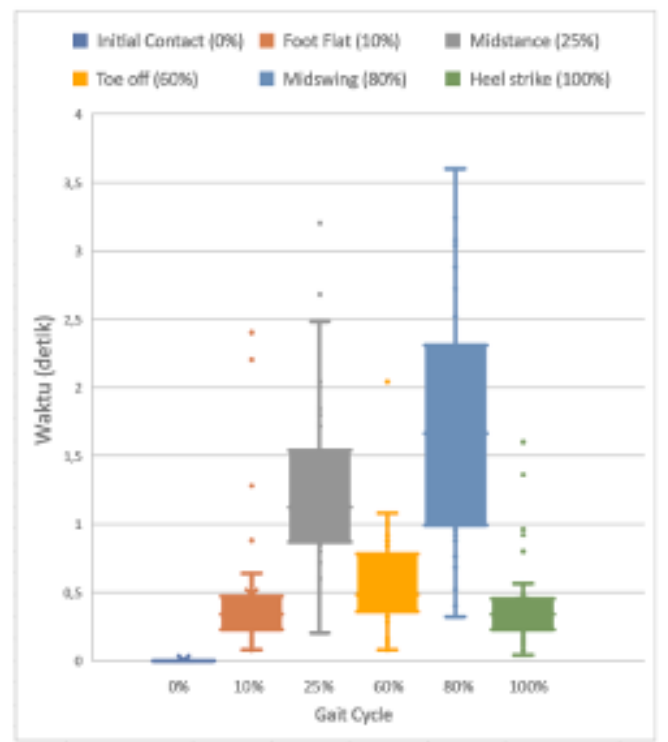

Gambar 4. Range waktu setiap rangkaian gait (gait sequences)

Tabel I merangkum data waktu dari rangkaian gait saat memanjat dengan dua fase, dengan total waktu rata-rata yakni 4,53 detik untuk satu gait cycle. Waktu gait cycle ini juga mengalami jangkauan yang lebar, yakni waktu tercepat 1,72 detik dan terlama 10,52 detik. Bila dikaji dari video, penderes dengan waktu tercepat ditunjukkan masih memanjat area bagian bawah pohon, sedangkan untuk waktu terlama terjadi pada penderes yang berusia lebih dari 60 tahun yang memanjat sampai tengah batang pohon. Perbedaan ini sesuai [29], bahwa semakin tinggi pohon yang dipanjat semakin tinggi energi yang dibutuhkan. Setiap penderes memiliki kebutuhan waktu masing-masing seperti pada Lampiran 1 . Waktu terlama untuk fase foot flat yakni 2,4 detik (penderes 21), midstance 3,2 detik (penderes 25), toe off 2,04 detik (penderes 25), midswing 3,6 detik (penderes 28), dan heel strike 1,6 detik (penderes 25).

TABEL I

RANGKUMAN ANALISIS GAIT SEOUENCE

\begin{tabular}{ccc}
\hline \multirow{2}{*}{ Fase } & \multicolumn{2}{c}{ Waktu (detik) } \\
\cline { 2 - 3 } & Rata-rata & Standar deviasi \\
\hline $\begin{array}{c}\text { Fase tumpuan } \\
\text { (stance) }\end{array}$ & 2,36 & 1,08 \\
Fase mengayun & 5,11 & 2,16 \\
$\quad($ swing) & 4,53 & 1,91 \\
Total Waktu & &
\end{tabular}

\section{Postur Kerja Penderes}

Analisis postur memanjat telah dilakukan di bidang keolahragaan, terkait biomekanika panjat tebing dan panjat dinding [9]. Sedikit berbeda dengan memanjat tebing, pergerakan penderes hanya ke arah vertikal dengan kaki bergantian bertumpu pada permukaan pohon. Sedangkan olah raga panjat tebing terjadi pergerakan vertikal dan horizontal menyesuaikan grip/kondisi batuan. Namun pada dasarnya analisis gerak dan postur dilakukan untuk mengefisienkan tenaga yang akan dikeluarkan, serta sudut yang terbentuk dari sendi dan koordinasi antara tangan dan kaki [30].

Berdasarkan rangkaian gait cycle, (Lampiran 1) posisi postur penderes saat memanjat dapat dibagi menjadi beberapa fase yakni awal (initial contact), salah satu kaki terangkat (foot flat), posisi salah satu kaki menumpu (midstance), kaki tumpuan diangkat dan lainnya menumpu (toe off), kaki pada posisi berayun (midswing), dan posisi kaki kembali ke posisi awal (heel strike).

1) Initial Contact (0\%): Posisi yang ditentukan sebagai patokan awal dan penanda akhir dari siklus gait, pada gait yang normal disebut pula heel contact (kontak tumit) dari satu kaki [31].

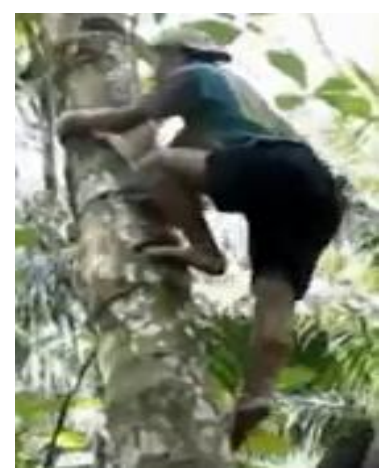

Gambar 5. Postur Kerja Memanjat [28] Posisi Initial Contact 
Pada aktivitas memanjat pohon posisi awal ditentukan pada saat salah satu kaki menapak pada pijakan pohon, karena saat memanjat telapak kaki menjadi tumpuan bukan pada kontak tumit. Hal ini dapat dilihat pada Gambar 5, yang menjadi posisi awal adalah kaki kiri didepan dalam kondisi menekuk dan kedua tangan memeluk pohon untuk menjaga keseimbangan.

TABEL II

EVALUASI POSTUR INITIAL CONTACT DENGAN REBA

\begin{tabular}{cccc}
\hline \multirow{2}{*}{ Evaluasi } & \multicolumn{3}{c}{ Skor REBA } \\
\cline { 2 - 4 } & Posisi & Tambahan & Nilai \\
\hline Leher & +2 & 0 & 2 \\
Badan & +1 & 0 & 1 \\
Kaki & +2 & +2 & 4 \\
Usaha & & +1 & $\mathbf{5}$ \\
Lengan Atas & +3 & 0 & 3 \\
Lengan Bawah & +2 & 0 & 2 \\
Pergelangan Tangan & +2 & +1 & 3 \\
Kopling & & +1 & $\mathbf{6}$ \\
Aktivitas & & +1 & $\mathbf{7}$ \\
Total Nilai & & & $\mathbf{8}$ \\
\hline
\end{tabular}

Pada posisi awal ini kedua kaki masih tertumpu, sehingga beban tubuh terdistribusi di kedua kaki dan waktu dimulai dari 0 detik. Posisi leher hyperextension, badan posisi tegap, kaki kiri ekstensi dengan lutut fleksi, perlahan melakukan penyimpanan tenaga, lengan atas fleksi (sejajar bahu), lengan bawah fleksi, pergelangan tangan ekstensi dan posisi menahan pohon dengan inversi, kondisi permukaan pohon kelapa yang masih dapat menahan pegangan, dan kondisi ini memiliki basis tumpuan yang tidak stabil. Berdasarkan hasil evaluasi dengan menggunakan REBA, postur kontak awal ini menunjukkan skor akhir 8 yang menunjukkan resiko tinggi. Untuk skor untuk masing-masing kriteria dapat dilihat pada Tabel II.

2) Foot Flat (10\%): posisi kaki kiri menapak dan menopang tubuh saat kaki kanan bergerak ke atas. Posisi tangan sebagai penyeimbang dan menahan berat tubuh seperti pada Gambar 6 .

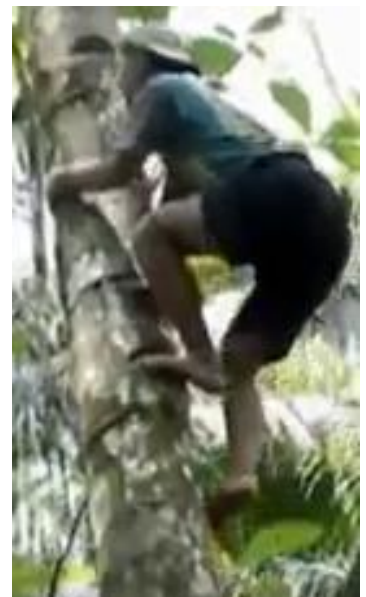

Gambar 6. Postur Kerja Memanjat [28] Posisi Foot Flat

Posisi leher hyperextension untuk melihat arah memanjat ke atas, badan posisi condong ke depan dan menarik badan mendekati pohon, kaki kiri ekstensi dengan lutut fleksi, perlahan melakukan penyimpanan tenaga, lengan atas fleksi (tidak melewati bahu), lengan bawah fleksi, pergelangan tangan ekstensi dan posisi menahan pohon dengan inversi, kondisi permukaan pohon kelapa yang masih dapat menahan pegangan, dan kondisi ini memiliki tumpuan yang tidak stabil.

TABEL III

EVALUASI POSTUR FOOT FLAT DENGAN REBA

\begin{tabular}{cccc}
\hline \multirow{2}{*}{ Evaluasi } & \multicolumn{3}{c}{ Skor REBA } \\
\cline { 2 - 4 } & Posisi & Tambahan & Nilai \\
\hline Leher & +2 & 0 & 2 \\
Badan & +2 & 0 & 2 \\
Kaki & +2 & +2 & 4 \\
Usaha & & +1 & $\mathbf{7}$ \\
Lengan Atas & +3 & +1 & 4 \\
Lengan Bawah & +2 & 0 & 2 \\
Pergelangan Tangan & +2 & +1 & 3 \\
Kopling & & +1 & $\mathbf{8}$ \\
Aktivitas & & +1 & $\mathbf{1 0}$ \\
Total Nilai & & & $\mathbf{1 1}$ \\
\hline
\end{tabular}

Berdasarkan hasil evaluasi dengan menggunakan REBA, postur foot flat ini menunjukkan skor akhir 11 yang menunjukkan resiko sangat tinggi dan perlu segera dilakukan implementasi perbaikan postur kerja. Untuk skor untuk masing-masing kriteria dapat dilihat pada Tabel III.

3) Midstance (25\%): pada posisi ini, kaki kanan mengayun dan kaki kiri menjadi tumpuan utama menahan berat tubuh, serta tangan berfungsi sebagai penyeimbang. Pada saat kaki mengayun ke atas bertumpu pada sendi pinggul (flexed-hip), terutama saat ischium akan bergerak memunculkan tenaga untuk mendorong tubuh ke atas [32].

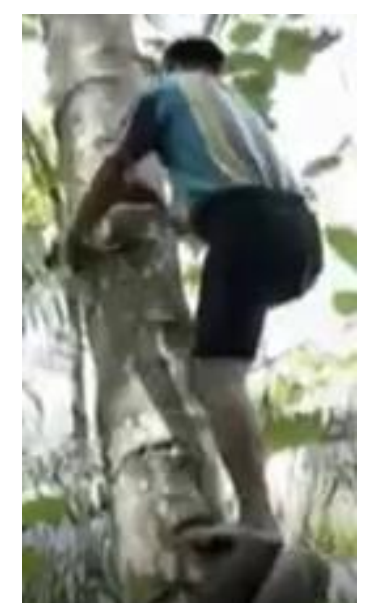

Gambar 7. Postur Kerja Memanjat [28] Posisi Midstance

Terlihat pada Gambar 7, posisi leher hyperextension, badan posisi mengarah ke depan, 
kaki kiri ekstensi dengan lutut fleksi kurang dari $60^{\circ}$, posisi menahan sehingga tidak ada usaha, lengan atas fleksi (sejajar bahu), lengan bawah ekstensi, pergelangan tangan ekstensi dan posisi inversi, kondisi permukaan pohon kelapa yang masih dapat menahan pegangan, dan kondisi ini memiliki basis tumpuan yang tidak stabil.

TABEL IV

EVALUASI POSTUR MIDSTANCE DENGAN REBA

\begin{tabular}{cccc}
\hline \multirow{2}{*}{ Evaluasi } & \multicolumn{3}{c}{ Skor REBA } \\
\cline { 2 - 4 } & Posisi & Tambahan & Nilai \\
\hline Leher & +2 & 0 & 2 \\
Badan & +2 & +1 & 3 \\
Kaki & +2 & +1 & 3 \\
Usaha & & 0 & $\mathbf{6}$ \\
Lengan Atas & +3 & 0 & 3 \\
Lengan Bawah & +1 & 0 & 1 \\
Pergelangan Tangan & +2 & +1 & 3 \\
Kopling & & +1 & $\mathbf{6}$ \\
Aktivitas & & +1 & $\mathbf{8}$ \\
Total Nilai & & & $\mathbf{9}$ \\
\hline
\end{tabular}

Berdasarkan hasil evaluasi dengan menggunakan REBA, postur mengayun kaki kanan (midstance) ini menunjukkan skor akhir 9 yang menunjukkan resiko tinggi, perlunya investigasi dan perubahan kondisi kerja. Untuk skor untuk masing-masing kriteria dapat dilihat pada Tabel IV.

4) Toe off (60\%): Posisi kaki kiri bersiap untuk mengangkat dan mengayun ke atas, tetapi masih pada posisi kedua kaki bertumpu. Pada kondisi berjalan normal, posisi pengangkatan kaki ini terjadi pada rangkaian gait cycle $60-62 \%$ yang membagi dua rangkaian menjadi fase tumpuan dan fase mengayunkan kaki [24]. Pada posisi ini tangan kiri berpindah dari posisi sejajar bahu ke posisi berada di atas, untuk menjangkau ke atas dan menjadi tumpuan agar tubuh dapat melakukan pergerakan ke atas.

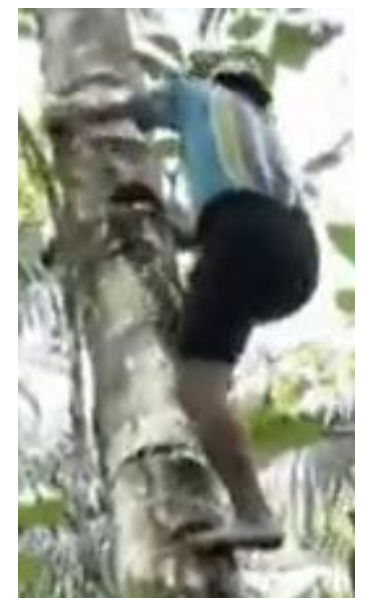

Gambar 8. Postur Kerja Memanjat [28] Posisi Initial Contact
Posisi leher hyperextension untuk memandang ke atas, badan posisi tegap dengan sedikit condong ke kanan, kaki kiri ekstensi dengan lutut fleksi kurang dari $60^{\circ}$, posisi kaki kiri menahan sehingga tidak ada usaha, lengan atas fleksi melewati tinggi bahu dengan adanya abduksi karena menjangkau ke atas, lengan bawah ekstensi, pergelangan tangan ekstensi dan posisi inversi, kondisi permukaan pohon kelapa yang masih dapat menahan pegangan, dan kondisi ini memiliki basis tumpuan yang tidak stabil, seperti Gambar 8.

TABEL V

EVALUASI POSTUR TOE OFF DENGAN REBA

\begin{tabular}{cccc}
\hline \multirow{2}{*}{ Evaluasi } & \multicolumn{3}{c}{ Skor REBA } \\
\cline { 2 - 4 } & Posisi & Tambahan & Nilai \\
\hline Leher & +2 & 0 & 2 \\
Badan & +1 & +1 & 2 \\
Kaki & +2 & +1 & 3 \\
Usaha & & 0 & $\mathbf{5}$ \\
Lengan Atas & +4 & +2 & 6 \\
Lengan Bawah & +1 & 0 & 1 \\
Pergelangan Tangan & +2 & +1 & 3 \\
Kopling & & +1 & $\mathbf{8}$ \\
Aktivitas & & +1 & $\mathbf{9}$ \\
Total Nilai & & & $\mathbf{1 0}$ \\
\hline Berclasarkan & & &
\end{tabular}

Berdasarkan hasil evaluasi dengan menggunakan REBA, postur toe off ini menunjukkan skor akhir 10 yang menunjukkan resiko tinggi, perlunya investigasi dan perubahan kondisi kerja. Untuk skor untuk masing-masing kriteria dapat dilihat pada Tabel V.

5) Midswing (80\%): Posisi kaki kiri mengayun ke atas dan kaki kanan menjadi tumpuan berat tubuh. Kondisi postur ini terbalik bila dibandingkan posisi midstance karena yang melakukan ayunan adalah kaki bagian kiri.

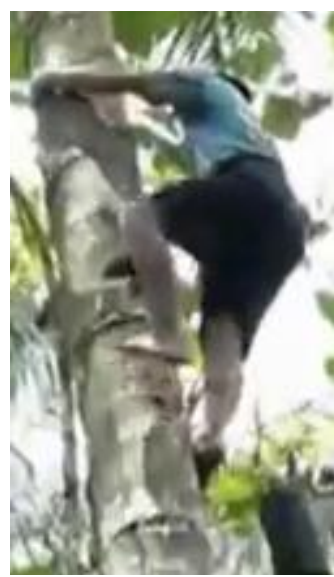

Gambar 9. Postur Kerja Memanjat [28] Posisi Midswing

Posisi leher hyperextension, badan posisi tegap dengan sedikit condong ke kanan, kaki kiri ekstensi dengan lutut fleksi, posisi kaki kiri mengayun sehingga ada usaha, lengan atas fleksi 
menjangkau di atas bahu dengan adanya abduksi dan bahu naik karena mengikuti lebar pohon dan otot biseps berkontraksi, lengan bawah ekstensi, pergelangan tangan ekstensi dan posisi inversi, kondisi permukaan pohon kelapa yang masih dapat menahan pegangan, dan kondisi ini memiliki basis tumpuan yang tidak stabil, seperti Gambar 9.

TABEL VI

EVALUASI POSTUR MIDSWING DENGAN REBA

\begin{tabular}{|c|c|c|c|}
\hline \multirow{2}{*}{ Evaluasi } & \multicolumn{3}{|c|}{ Skor REBA } \\
\hline & Posisi & Tambahan & Nilai \\
\hline Leher & +2 & 0 & 2 \\
\hline Badan & +1 & +1 & 2 \\
\hline Kaki & +2 & +2 & 4 \\
\hline Usaha & & +1 & 7 \\
\hline Lengan Atas & +4 & +2 & 6 \\
\hline Lengan Bawah & +1 & 0 & 1 \\
\hline Pergelangan Tangan & +2 & +1 & 3 \\
\hline Kopling & & +1 & 8 \\
\hline Aktivitas & & +1 & 9 \\
\hline Total Nilai & & & 11 \\
\hline Berdasarkan & hasil & evaluasi & deng \\
\hline $\begin{array}{l}\text { menggunakan } \\
\text { menunjukkan sk } \\
\text { resiko sangat tin } \\
\text { implementasi per } \\
\text { untuk masing-ms } \\
\text { Tabel VI. }\end{array}$ & $\begin{array}{l}\text { BA, } \\
\text { akhir } \\
\text { i dan } \\
\text { ikan p } \\
\text { ag krit }\end{array}$ & $\begin{array}{l}\text { stur mids } \\
\text { yang me } \\
\text { rlu segera } \\
\text { tur kerja. L } \\
\text { ia dapat di }\end{array}$ & $\begin{array}{l}n g \\
\text { njukk } \\
\text { lakuk } \\
\text { uk sk } \\
\text { lat pa }\end{array}$ \\
\hline
\end{tabular}

6) Heel strike (100\%): Posisi postur kembali ke posisi semula (initial contact), saat kaki kiri menyentuh pijakan pada pohon yang menandakan selesainya satu siklus rangkaian gait. Posisi leher masih hyperextension, badan posisi condong ke depan karena menari tubuh ke atas, kaki kiri ekstensi dengan lutut fleksi, melakukan gerakan yang membutuhkan tenaga tiba-tiba, lengan atas fleksi ke atas melebihi bahu, lengan bawah fleksi, pergelangan tangan ekstensi dan posisi menahan pohon dengan inversi, kondisi permukaan pohon kelapa yang masih dapat menahan pegangan, dan kondisi ini memiliki basis tumpuan yang tidak stabil. Postur posisi heel strike ini dapat dilihat pada Gambar 10.

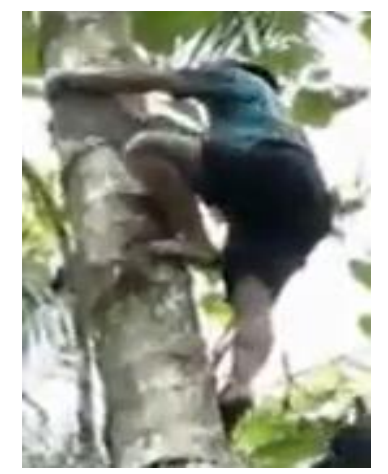

Gambar 10. Postur Kerja Memanjat [28] Posisi Heel Strike

\section{JMTSS lisinatum}

Berdasarkan hasil evaluasi dengan menggunakan REBA, postur midswing ini menunjukkan skor akhir 9 yang menunjukkan resiko tinggi, perlunya investigasi dan perubahan kondisi kerja. Untuk skor untuk masing-masing kriteria dapat dilihat pada Tabel VII.

TABEL VII

EVALUASI POSTUR HEEL STRIKE DENGAN REBA

\begin{tabular}{cccc}
\hline \multirow{2}{*}{ Evaluasi } & \multicolumn{3}{c}{ Skor REBA } \\
\cline { 2 - 4 } & Posisi & Tambahan & Nilai \\
\hline Leher & +2 & 0 & 2 \\
Badan & +2 & 0 & 2 \\
Kaki & +2 & +2 & 4 \\
Usaha & & +1 & $\mathbf{6}$ \\
Lengan Atas & +4 & 0 & 4 \\
Lengan Bawah & +1 & 0 & 1 \\
Pergelangan Tangan & +2 & +1 & 3 \\
Kopling & & +1 & $\mathbf{5}$ \\
Aktivitas & & +1 & $\mathbf{6}$ \\
Total Nilai & & & $\mathbf{9}$ \\
\hline
\end{tabular}

\section{IV.PEMBAHASAN}

Postur dan posisi saat melakukan aktivitas kerja memiliki keterkaitan dengan penyakit otot rangka dan keluhan punggung bawah (low back pain) yang meningkat setalah berusia 40 tahun. [1]. Semakin besar resiko dari postur, maka semakin besar terjadinya keluhan otot yang dapat mengakibatkan cidera hingga kecelakaan kerja. Maka semakin besar resiko dari kondisi kerja, perlu penanganan yang lebih.

\section{A. Hasil REBA}

Dengan menggunakan Rapid Entire Body Assessment (REBA) pada postur penderes, dapat dilihat pada skor Tabel VIII bahwa pekerjaan petani kelapa (terutama saat memanjat pohon) berisiko tinggi. Secara garis besar keenam postur memanjat bernilai skor REBA 8 sampai 11 . Sedangkan nilai skor terbesar yakni 11 terjadi pada postur posisi foot flat $(10 \%)$ dan midswing $(80 \%)$.

TABEL VIII

RANGKUMAN ANALISIS POSTUR DENGAN REBA

\begin{tabular}{cc}
\hline Rangkaian Gait & Skor REBA \\
\hline Initial Contact $(0 \%)$ & 8 \\
Foot Flat $(10 \%)$ & 11 \\
Midstance $(25 \%)$ & 9 \\
Toe off $(60 \%)$ & 10 \\
Midswing $(80 \%)$ & 11 \\
Heel strike $(100 \%)$ & 9 \\
\hline
\end{tabular}

Gambar 11 menunjukkan posisi-posisi anggota badan yang dievaluasi dengan REBA berdasarkan rangkaian gait. Pada posisi foot flat resiko terbesar ada pada lengan atas, kaki, dan pergelangan 
tangan, berbeda halnya dengan posisi midswing resiko terbesar ada pada lengan atas dan kaki..

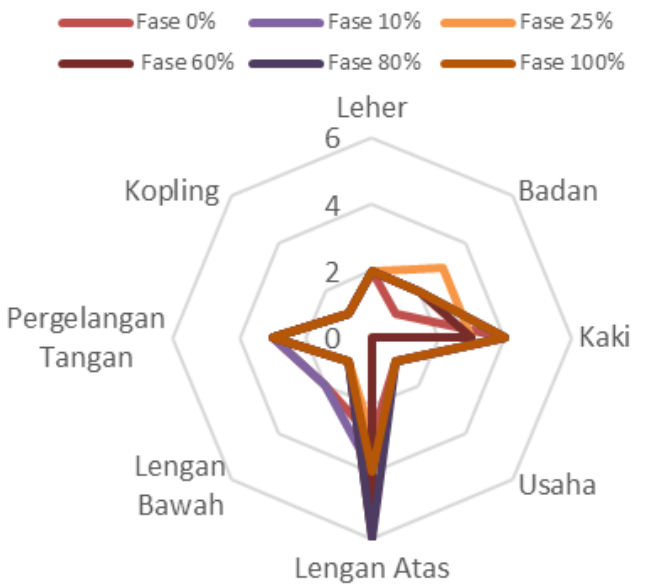

Gambar 11. Hasil Evaluasi Postur Penderes dengan REBA

Bila dibandingkan dengan data waktu terlama saat memanjat pada Gambar 3, nilai skor resiko REBA pada Tabel VIII meningkat berkaitan dengan kondisi lengan atas sedangkan kebutuhan waktu untuk memanjat berdasarkan kondisi ayunan kaki.

\section{B. Perbaikan Postur Kerja}

Hasil REBA ini selaras dengan [5][16][20] yang menunjukkan bahwa pekerjaan pemanjat kelapa bernilai resiko tinggi. George dkk [20] juga menyimpulkan bahwa para profesional pemanjat kelapa mengalami perubahan secara biomekanika bila bekerja 5-6 jam setiap hari saat melakukan pekerjaan mereka, yang mengarah pada perubahan anatomi dan fungsional utama pada kaki mereka. Salah satu yang mungkin mempengaruhi penderes jatuh dari pohon kelapa saat bekerja terlihat pada pendaki yang lebih berpengalaman karena jumlah pronasi dan supinasi yang tidak normal menyebabkan berbagai masalah kaki dan tungkai. Dalam penelitian [19] juga menemukan bahwa gerakan lengan di atas tingkat bahu dapat jauh lebih meningkatkan denyut jantung dibandingkan dengan gerakan lengan di bawah tingkat bahu. Unsur yang perlu dipertimbangkan adalah keseimbangan dalam menempatkan tubuh (pijakan kaki dan genggaman tangan) bukan memusatkan pada pegangan tangan untuk mengangkat tubuh karena akan mempercepat kelelahan [9][30].

Untuk mencapai target ekspor gula aren yang dicanangkan pemerintah daerah perlu dilakukan penerapan ergonomi saat memanjat mengambil nira dalam rangka mengurangi kecelakaan dan penyakit akibat kerja. Beberapa contoh diantaranya menggunakan tangga untuk mengurangi energi ekspenditur [29] dan kursi panjat safety untuk mengurasi resiko postur kerja [5]. Solusi ini tentunya akan mengurangi angka resiko karena postur berasosiasi dengan beban kerja, tetapi dari segi waktu para penderes lebih memilih memanjat tanpa menggunakan safety belt terkendala pada kepraktisan bila harus memanjat banyak pohon [16]. Oleh karena itu implementasi ergonomi harus didukung oleh berbagai pihak baik dari pemerintah, lembaga masyarakat, asosiasi, universitas, kelompok usaha, perbankan dan dunia usaha [14]. Penerapan ergonomi tidak hanya meningkatkan kenyamanan dan keamanan yang dirasakan pekerja, tetapi juga meningkatkan efisiensi serta produktivitas kerja

\section{Keterbatasan dan Penelitian Selanjutnya}

Evaluasi postur penderes pada studi ini hanya pada saat memanjat kelapa. Sedangkan aktivitas pengambilan gula kelapa terdiri dari tiga tahap yakni memanjat pohon kelapa, mengambil nira, dan menuruni pohon, yang masing-masing memiliki resiko terjatuh. Kondisi lingkungan kerja juga patut dipertimbangkan selanjutnya karena penderes harus tetap memanjat walau dalam kondisi hujan atau panas terik. Video dalam penelitian ini juga terbatas pada data sekunder, dan hampir setiap video diambil berdasarkan level ketinggian mata dari orang yang melakukan perekaman gambar sehingga membentuk sudut dalam mengobservasi. Untuk penelitian selanjutnya perlu dilakukan pengambilan video dan data meminimalkan bias pada evaluasi postur.

Analisis biomekanik yang komprehensif menggunakan simulasi dan pemodelan juga diperlukan. Aktivitas memanjat bukanlah postur statis, aktivitas ini perlu mempertimbangkan pergerakan tubuh saat kondisi dinamis. Han dkk [33] melakukan penelitian terkait stress fisik yang terjadi saat memanjat tangga menggunakan motion capture, sedangkan Cha dkk [34] melakukan analisis postur memanjat dengan kombinasi motion capture dan animasi 3 dimensi. Terlebih tidak semua parameter gait [31] dipertimbangkan dalam studi ini yakni durasi siklus relatif, panjang stride, kecepatan, cadence, usaha saat menapak, dan lainnya yang berpengaruh pada pergerakan dan kapabilitas tubuh.

\section{KESIMPULAN}

Terdapat enam posisi postur penderes memanjat pohon kelapa yang dianalisis berdasarkan rangkaian gait berjalan secara 
vertikal. Rangkaian gait saat memanjat terdiri dari dua fase, dengan total waktu rata-rata yakni 4,53 $( \pm 1,91)$ detik untuk satu gait cycle. Analisis postur dengan REBA menunjukkan postur kerja pada saat memanjat bernilai tertinggi yaitu 11 pada postur posisi foot flat (10\%) dan midswing (80\%). Sedangkan untuk postur lainnya dalam range 8 sampai 10 . Kondisi ini beresiko tinggi sehingga dibutuhkannya perbaikan segera pada postur kerja untuk meningkatkan keamanan dan kenyamanan kerja penderes.

\section{REFERENSI}

[1] T. Susanto, R. Purwandari, and E. Wuri Wuryaningsih, "Prevalence and associated factors of health problems among Indonesian farmers," Chinese Nurs. Res., vol. 4, no. 1, pp. 31-37, Mar. 2017.

[2] S. Iftikar Z., A. Ruhana, and T. Jann H., Teknik Perancangan Sistem Kerja. ITB Bandung, 2006.

[3] V. Silviyani, T. Susanto, and N. Asmaningrum, "Hubungan Posisi Bekerja Petani Lansia dengan Resiko Terjadinya Nyeri Punggung Bawah di Wilayah Kerja Puskesmas Sumberjambe Kabupaten Jember," Artik. Ilm. Has. Penelit. Mhs., pp. 1-8, 2013.

[4] F. . Gunawan and W. Martowiyoto, Risk Based Behavioral Safety. Gramedia Pustaka Utama, 2015.

[5] A. Mohankumar, D. A. Krishnan, and K. Kathirvel, "Development of ergo refined coconut tree climbing device.” 2013.

[6] R. S. Bridger, Introduction to Ergonomics, Third Edition. CRC Press, 2008.

[7] S. N. Salehhodin, B. Abdullah, and A. Yusoff, "Comparison Level of Handgrip Strength for the Three Categories among Male Athleteâ $\square{ }^{\mathbf{T M}_{S}}$ Artificial Wall Climbing and Factors WILL Affect," Int. J. Acad. Res. Bus. Soc. Sci., vol. 7, no. 14, pp. 272-285, 2018

[8] J. Baláš, O. Pecha, A. J. Martin, and D. Cochrane, "Hand-arm strength and endurance as predictors of climbing performance," Eur. J. Sport Sci., vol. 12, no. 1, pp. 16-25, 2012.

[9] D. Nugroho, "Analisis Gerak Dasar Panjat Tebing," J. Phederal Penjas, vol. 9, no. 2, 2014.

[10] Primasadi, "Gula Kelapa Banyumas Riwayatmu Kini dan Nanti," LPPSLH, 2018. [Online]. Available: https://www.lppslh.or.id/artikel/gulakelapa-banyumas-riwayatmu-kini-dan-nanti/. [Accessed: 26-Sep-2019].

[11] I. Indarwati, "Efisiensi Produksi Pada Agroindustri Gula Kelapa Di Kecamatan Cilongok Kabupaten Banyumas," Maj. Ilm. Ekon., vol. 12, no. 3, pp. 109179, 2009.

[12] F. G. Sudarsono, "Faktor-Faktor Penentu Lokasi Sentra Industri Gula Kelapa (Studi Kasus: Di Wilayah Kecamatan Nglegok, Kabupaten Blitar)," $J$. Ilm. Mhs. FEB, vol. 2, no. 2, 2013.

[13] D. D. Hendaryati and Y. Arianto, "Statistik Perkebunan Indonesia Komoditas Kelapa 20152017," 2016

[14] Dekopinda Banyumas, "Banyumas Meningkatan Kualitas dan Kuantitas Gula Kelapa," Dekopinda Banyumas, 2019. [Online]. Available: http://www.dekopindabanyumas.org/2019/08/banyumas-meningkatankualitas-kuantitas.html. [Accessed: 26-Sep-2019].

[15] P. K. Utami, "Penderes Nira Mulai Langka di Desa
Penghasil Gula Merah," Gatra, 2019. [Online]. Available:

https://www.gatra.com/detail/news/445533/ekonomi /penderes-nira-mulai-langka-di-desa-penghasil-gulamerah. [Accessed: 27-Sep-2019].

[16] R. A. Imran, D. M. Kusmawati, and Industri, "Identifikasi Organisasi Keselamatan Kerja Petani Gula Kelapa dengan Pendekatan Sociotechnical System di Kabupaten Banyumas," Pros. Semin. Nas. Teknol. Ind. VI, pp. 1-6, 2018.

[17] A. Husein, "Kebijakan pemerintah kabupaten banyumas dalam pengembangan industri kecil gula kelapa," p. 29, 2015.

[18] O. Jasnari, H. Isnurdiansyah, and J. Tengah, "Benarkah gula kelapa rasanya manis ?," pp. 7-9.

[19] S. Burnik and B. Jereb, "Heart rate as an indicator of sport climbing intensity," Acta Univ. Palacki, vol. 37, no. 1, pp. 63-66, 2007.

[20] B. M. George, A. Kumar, and M. S. Rao, "Biomechanics of climbing coconut trees and its implications in ankle foot morphology- a video sequence analysis," J. Clin. Diagnostic Res., vol. 7, no. 5, pp. 790-793, 2013

[21] P. Edacheri, D., Kumar, S. and Unakal, Design of a coconut tree climbing device. 2011.

[22] H. E. Effendi, "Penderes di Banyumas Minim Generasi - Cendana News," Cendana News, 2019. [Online]. Available: https://www.cendananews.com/2019/08/penderesdi-banyumas-minim-generasi.html. [Accessed: 30Sep-2019]

[23] Gloria, "Mahasiswa UGM Menciptakan Alat Penderes Nira Otomatis | Universitas Gadjah Mada," UGM, 2016. [Online]. Available: https://ugm.ac.id/id/berita/11921-mahasiswa-ugmmenciptakan-alat-penderes-nira-otomatis. [Accessed: 30-Sep-2019].

[24] C. Kirtley, Clinical gait analysis: theory and practice. Elsevier, 2006.

[25] S. Hignett and L. McAtamney, "Rapid entire body assessment (REBA).," Appl. Ergon., vol. 31, no. 2, pp. 201-5, Apr. 2000.

[26] T. Susanto, R. Purwandari, and E. W. Wuryaningsih, "Model Perawatan Kesehatan Keselamatan Kerja Berbasis Agricultural Nursing: Studi Analisis Masalah Kesehatan Petani," J. NERS, vol. 11, no. 1, p. 45, 2016.

[27] T. S. Kraft, V. V. Venkataraman, and N. J. Dominy, "A natural history of human tree climbing," J. Hum. Evol., vol. 71, pp. 105-118, Jun. 2014.

[28] C. Setiyawan, Tungku Penderes Gula Kelapa YouTube. CSI Film \& Design Competition, 2014

[29] Z. binti Yusof and D. El Pebrian, "Analysis of human energy expenditure in harvesting sugar palm (Arenga Pinnata Merr) in Malaysia," Agric. Eng. Int. CIGR J., vol. 18, no. 1, pp. 149-157, 2016.

[30] Munasifah, Mengenal Olahraga Panjat Tebing. Semarang: CV. Ghyyas Putra, 2008.

[31] M. Whittle, Gait analysis: an introduction. Butterworth-Heinemann, 2007.

[32] E. E. Kozma et al., "Hip extensor mechanics and the evolution of walking and climbing capabilities in humans, apes, and fossil hominins," Proc. Natl. Acad. Sci., vol. 115, no. 16, pp. 4134-4139, 2018.

[33] S. Han, S. Lee, and T. J. Armstrong, "Markerless Motion Tracking to Study Physical Stresses During Climbing," pp. 1-6.

[34] K. Cha, E. Y. Lee, M. H. Heo, K. C. Shin, J. Son, and D. Kim, "Analysis of climbing postures and movements in sport climbing for realistic 3D climbing animations," Procedia Eng., vol. 112, pp. 52-57, 2015. 
Imran, Purnamasari, Sibarani

LAMPIRAN 1

Range Fase Setiap Rangkaian Gait (Gait Sequences) dari Penderes

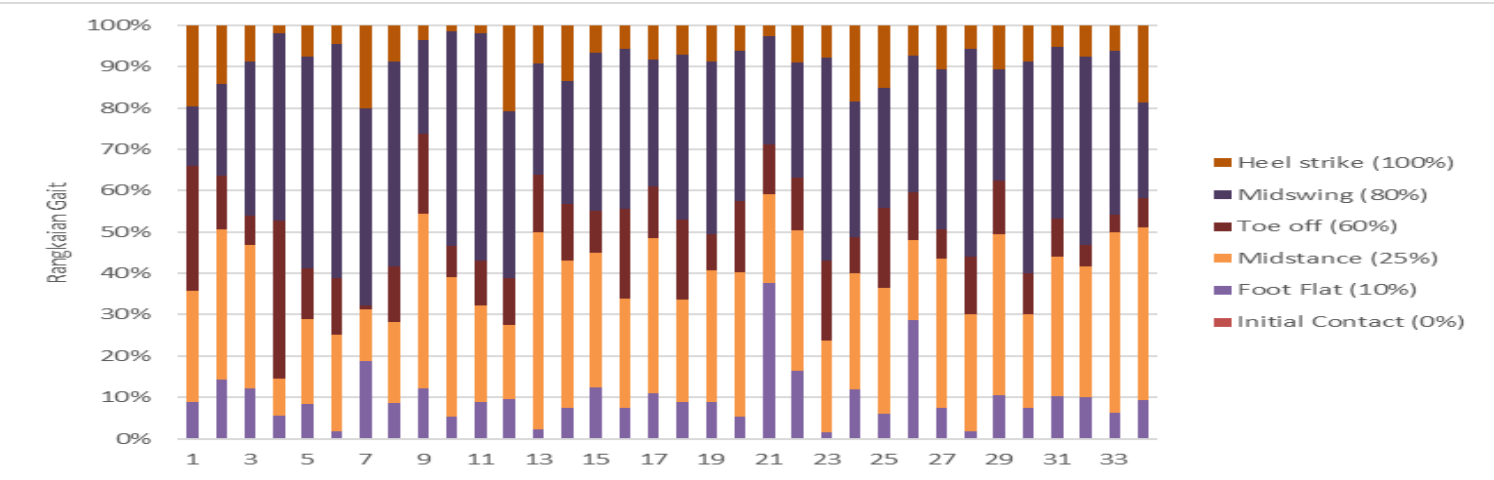

